\title{
Спеціальна фізична підготовленість висококваліфікованих більярдистів як чинник підвищення ефективності змагальної діяльності (на прикладі пулу)
}

\section{Ольга Борисова, Вікторія Нагорна, Артур Митько}

Національний університет фрізичного виховання і спорту України, Київ, Україна

Анотація. У статті розглянуто проблеми удосконалення рівня спеціальної фізичної підготовленості висококваліфікованих більярдистів для підвищення ефективності їхньої змагальної діяльності та досягнення високих спортивних результатів на головних міжнародних змаганнях з пулу.

Аналіз сучасних програм підготовки висококваліфікованих більярдистів провідних збірних команд Європи з пулу, в тому числі й України, дозволив визначити, що їхній зміст складається переважно $з$ показників планування тренувального навантаження технікотактичної підготовленості без урахування диференційованого підходу до розвитку та удосконалення спеціальних фрізичних якостей.

Одним зі шляхів вирішення зазначеної проблеми має стати розробка та впровадження у підготовку збірної команди України комплексних програм із урахуванням рівня психологічної, техніко-тактичної та спеціальної фрізичної підготовленості гравців. Мета. Підвищення ефективності підготовки більярдистів високої кваліфікації до головних змагань макроциклу шляхом оптимізації рівня спеціальної фізичної підготовленості. Методи. Аналіз і узагальнення науково-методичної літератури; опитування; метод експертних оцінок; спостереження; тестування, педагогічний експеримент; психофрізіологічні методи дослідження; методи математичної статистики. Результати. Реалізація розробленої нами програми підготовки спортсменів до головних змагань макроциклу у педагогічному експерименті виявила вірогідне поліпшення інтегральної підготовленості в експериментальній групі більярдистів національної збірної команди $з$ пулу до чемпіонату Європи порівняно з контрольною групою $(p<0,05)$. Наукове обгрунтування практичної ефрективності впровадження у процес підготовки національно збірної команди з більярдного спорту (пул) підтверджено високими результатами виступів висококваліфікованих більярдистів на чемпіонатах Європи з пулу 2016-2019рр. Ключові слова: більярдний спорт, пул, спеціальна фрізична підготовка, інтегральна підготовка, програма підготовки, індивідуальний план.

\section{Olha Borysova, Viktoriia Nagorna, Artur Mytko}

\section{SPECIFIC PHYSICAL FITNESS OF ELITE BILLIARDS PLAYERS AS A FACTOR IN IMPROVING THE EFFECTIVENESS OF COMPETITIVE ACTIVITIES (AS EXEMPLIFIED BY POOL)}

Abstract. The article deals with the issue of improving the level of specific physical fitness of elite billiards players to increase the efficiency of their competitive activities and achieve high sports performance at major international pool competitions.

An analysis of modern training programs for elite billiards players of the leading pool teams in the Europe, including Ukraine, revealed that their content consists mainly of indicators of planning the amount of technical and tactical training without taking into account the differentiated approach to development and improvement of specific physical qualities.

One of the ways to solve this problem should be the development and implementation of comprehensive programs in the training of the national team of Ukraine, taking into account the level of psychological, technical, tactical, and specific physical fitness of players.

Borysova 0., Nagorna V., Mytko A. Specific physical fitness of elite billiards players as a factor in improving the effectiveness of competitive activities (as exemplified by pool). Theory and Methods of Physical education and sports. 2021; 3: 14-19 DOI: 10.32652/tmfvs.2021.3.14-19
Борисова О., Нагорна В., Митько А..

Спеціальна фізична підготовленість висококваліфікованих більярдистів як чинник підвищення ефективності змагальної діяльності (на прикладі пулу). Теорія і методика фрізичного виховання і спорту. 2021; 3: 14-19

DOI: 10.32652/tmfvs.2021.3.14-19
20. Olympic Training Centers [Internet]. Available from: www.teamusa.org/For-Athletes/Olympic-Training-Centers-and-Sites.aspx

Надійшла 08.09.2021

Вступ. У спорті вищих досягнень основною метою кожного учасника $€$ досягнення найвищого спортивного результату на головних міжнародних змаганнях в обраному виді спорту. I якщо раніше домінуючим джерелом приросту спортивної результативності фахівці вважали збільшення тренувальних навантажень, то сьогодні провідні науковці та тренери віддають першість саме ефективній побудові тренувального процесу $[10,12]$. Існує велика кількість наукових робіт [1, 6 , $7,11,12]$, присвячених темі підвищення ефективності змагальної діяльності висококваліфрікованих спортсменів 3 акцентом на оптимізацію процесу їх підготовки до Олімпійських ігор. На жаль, не так багато наукових доробок стосуються підвищення ефективності управління тренувальною та змагальною діяльністю висококваліфікованих спортсменів 3 неолімпійських видів спорту [9].

Більярдний спорт, представлений трьома основними видами (карамболь, пул, снукер), включено до програми Всесвітніх ігор у 2001 р. Для України пул є молодим видом у контексті спорту вищих досягнень, та все ж українські більярдисти мають здобутки на міжнародних змаганнях найвищого рівня. Важливою подією для країни стало проведення | Європейських ігор (з неолімпійських видів спорту) у 2007 р. у столиці нашої держави, де був представлений більярдний спорт, а саме - пул, дисципліна «Пул-9». На цих змаганнях українські більярдисти стали призерами. За останні роки результати виступів національної збірної команди з пулу на міжнародній арені значно покращили- 
Objective. Improving the efficiency of preparation of elite billiards players for the main competitions of the macrocycle by optimizing the level of specific physical training. Methods. Analysis and generalization of scientific and methodological literature; survey; method of expert assessment; observation; testing, pedagogical experiment; psychophysiological methods; and methods of mathematical statistics. Results. The implementation of the developed by us program for preparing athletes for the main competitions of the macrocycle in the pedagogical experiment revealed a significant improvement of the integrated preparedness in the experimental group of billiards players of the national pool team for the European Championship compared to the contro group $(p<0.05)$. The scientific substantiation of the practical effectiveness of the implementation in the training process of the national billiards team (pool) is confirmed by the high performance of elite billiards players at the European Pool Championships 2016-2019.

Keywords: billiards, pool, specific physical training, integrated preparation, training program individual plan.

ся, проте поки що жоден спортсмен не отримав ліцензію для участі у Всесвітніх іграх.

Аналіз сучасної наукової літератури та передового досвіду свідчить, що використання модельних характеристик тренувальної та змагальної діяльності найкращих спортсменів світу дозволяє своєчасно й об'єктивно оцінювати стан спортсмена і вносити корективи до тренувальних завдань 3 метою індивідуалізації тренувального процесу [5, 8, 12]. На сьогодні у більярдному спорті розроблено лише окремі компоненти модельних характеристик техніко-тактичної та змагальної підготовленості, а моделі фрізичної підготовленості взагалі відсутні. Сучасні програми підготовки в більярдному спорті досить неоднорідні: рекреаційного спрямування, акцентовані на масовий спорт, ссрокусовані лише на вдосконаленні техніко-тактичної підготовленості без урахування дисеренційованого підходу до розвитку й удосконалення спеціальних фізичних якостей висококваліфікованих більярдистів [2-4, 8, 13]. Усе це свідчить про актуальність питання підвищення конкурентоспроможності українських пулістів у сучасних умовах змагань.

Мета дослідження - підвищення ефективності підготовки більярдистів високої кваліфікації до головних змагань макроциклу шляхом оптимізації рівня спеціальної фрізичної підготовленості.

Методи досліджень. Теоретичний аналіз науково-методичної літератури та документальних матеріалів; опитування, метод експертних оцінок; спостереження, тестування, педагогічний експеримент, психосрізіологічні методи; методи математичної статистики.

Результати дослідження та їх обговорення. Аналіз спеціальної літератури дозволив детально оцінити стан наукової проблеми, обґрунтувати актуальність теми дослідження, сфрормулювати завдання та здійснити вибір адекватних методів дослідження для більярдистів національної збірної команди України. Соціологічні методи включали використання опитування та опосередковане спілкування з тренерами та функціонерами країнучасниць чемпіонату Європи 3 пулу для характеристики розвитку більярдного спорту та аналізу програм підготовки спорту вищих досягнень.

Метод експертних оцінок у дослідженні використовували для тренерів збірних команд ( $n=30)$ та кращих спортсменів $(\mathrm{n}=90)$ країн Європи 3 пулу з метою визначення основних пріоритетів розподілу навантаження спортивної підготовки в пулі на макроцикл, профрілюючих видів фізичних здібностей та необхідність спеціальної фрізичної підготовки для більярдного спорту.

у ході дослідження було використано педагогічні методи, які включали: педагогічне спостереження - для визначення суб'єктивних показників рівня інтегральної підготовленості висококваліфікованих більярдистів; педагогічне тестування - для оцінювання та аналізу рівня техніко-тактичної, інтегральної, змагальної та спеціальної фізичної підготовленості висококваліфікованих більярдистів; педагогічний експеримент - для встановлення та характеристики рівня спеціальної фрізичної підготовленості спортсменів національної збірної команди Украї- ни з більярдного спорту (пул) за допомогою тестових вправ, що увійшли до змісту розроблених програм підготовки.

Психофрізіологічні методи дослідження використовували для визначення обсягу та ефективності уваги, стресостійкості, продуктивності, короткострокової зорової пам'яті, якості функції рівноваги. Математичностатистичну обробку й аналіз даних проводили 3 використанням обчислювальних і графрічних можливостей комп'ютерних програм «Statistica» (Statsoft, версія 7.0) та Microsoft Excel 2010.

Аналіз вивчення стану проблеми дозволив встановити, що всі види більярдного спорту (пул, снукер, карамболь, піраміда, блекбол, артистичний більярд тощо) вимагають від гравця високої точності рухів та уваги для якісного виконання техніки одного 3 близько 60 видів ударів. Спортсмен має враховувати такі фрактори: сила удару, прискорення та траєкторія руху кулі, ворсистість сукна, пружність гуми, а також свій психічний та фрізичний стани. У цьому виді гри балістичні рухи пов'язані з ударами києм по кулі, що має потрапити в конкретну точку простору. У зв'язку з цим ми можемо говорити про таку рухову якість, як влучність, котра обумовлена кількома параметрами точності: диференціювання амплітуди рухів та зусиль, що докладають до предмета, і визначення відстані до заданої точки. Саме тому у багаторічній підготовці спортсменів на етапах підготовки до вищої спортивної майстерності та максимальної реалізації індивідуальних можливостей у більярдному спорті під час планування навантажень за видами спортивної підготовки необхідно приділяти увагу не тільки техніко-тактичній та психологічній, а й спеціальній фрізичній підготовці гравців. Необхідна чітка відповідність системи тренування висококваліфікованих спортсменів специфічним вимогам обраного для спеціалізації виду - більярдного спорту, а конкретно - пулу.

Ретроспективний аналіз спеціальної та науково-методичної літератури, педагогічне спостереження та опитування фрахівців засвідчує, що вико- 
Іेнтегральна (ігрова) підготовка

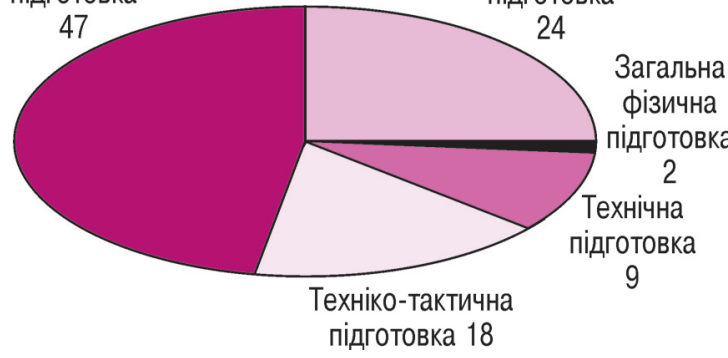

Специфічна фізична підготовка
Рисунок 1 - Розподіл видів підготовки більярдистів національної збірної команди України під час педагогічного експерименту, \%

ристання модельних характеристик тренувальної та змагальної діяльності найкращих спортсменів світу дозволяє своєчасно й об'єктивно оцінювати їхній стан і вносити корективи до тренувальних завдань з метою індивідуалізації тренувального процесу. Але у більярдному спорті фрахівцями досі розглядалися лише окремі компоненти модельних характеристик техніко-тактичної та змагальної підготовленості без урахування такого важливого на етапах підготовки до вищої спортивної майстерності та максимальної реалізації індивідуальних можливостей у більярдному спорті виду, як спеціальна фрізична підготовленість.

Опитування провідних фрахівців у ссрері більярду, аналіз експертних думок та об'єктивне зростання показників тривалості та величини статодинамічних навантажень у змагальній діяльності висококваліфікованих більярдистів за останні роки обумовило удосконалення програми підготовки на основі підвищення ефективності спеціальної фрізичної підготовки гравців національної збірної команди України. Результати дослідження дозволили розробити програму, яка включає диференційоване навантаження зі спеціальної фрізичної підготовки 3 акцентом на вдосконалення спеціальних координаційних здібностей та витривалості.

Як видно із рисунка 1, на спеціальну фрізичну підготовку (СФП) більярдистів національної збірної команди України відводилося 24,5 \% загального часу тренувань, при цьому загальна фрізична підготовка (ЗФП) займала 1,7 \%. Для технічної підготовки використовували 8,6 \% тренувального часу на рік, на техніко-тактичну підготовку - 17,6 \%. Таким чином,
47,6 \% загального тренувального часу спортсмени виконували навантаження з інтегральної (ігрової) підготовки.

Реалізація програми дозволила обґрунтувати один із напрямів підвищення ефективності тренувального процесу висококваліфрікованих більярдистів у змагальному періоді в пулі, що ґрунтується на використанні дифреренційного нормування тренувальних навантажень зі спеціальної фрізичної підготовки залежно від індивідуальних особливостей спортсменів та дисципліни пулу або кількох, що представлені на головних змаганнях макроциклу.

Зміст розроблених нами індивідуальних програм (планів) для спортсменів національної збірної команди 3 пулу представлено у вигляді моделі побудови змагального періоду, а конкретно - на етапі безпосередньо підготовки до головних змагань макроциклу - чемпіонату Європи з пулу, яка складається 3 мезоциклів - 8 тижнів: перший - базовий, 2 тижні, коли тренувальний процес спрямовано на збірної команди до чемпіонату Європи з пулу усунення диспропорції в компонентах спеціальної підготовленості завдяки акцентованому удосконаленню специфрічних для конкретної дисципліни пулу фрізичних якостей; другий - спеціально-підготовчий, 4 тижні, передбачає розвиток необхідних спортсмену техніко-тактичних компонентів; третій - передзмагальний, 2 тижні, спрямований на досягнення високого рівня спеціальної підготовленості та тренованості на день змагань (рис. 2).

До змісту програми увійшли як авторські техніко-тактичні вправи, так і ті, що були розроблені провідними тренерами Європи 3 пулу. Основною концептуальною ідеєю в розробці змісту програми стала диференціація видів навантаження, інтервалів відпочинку, координаційної складності, кількості ударів та тривалості концентрації уваги при суворому регламентуванні виконання техніко-тактичних елементів 3 акцентом на вдосконалення координаційних здібностей та спеціальної витривалості. Впровадження розробленої програми у тренувальний процес національної збірної з більярдного спорту (пул) спонукав до підвищення результату виступу наших спортсменів на чемпіонаті Європи $з$ пулу.

у кожному макроциклі під час навчально-тренувальних зборів і безпосередньої підготовки до головних змагань визначали рівень спеціальної фрізичної підготовленості високо-

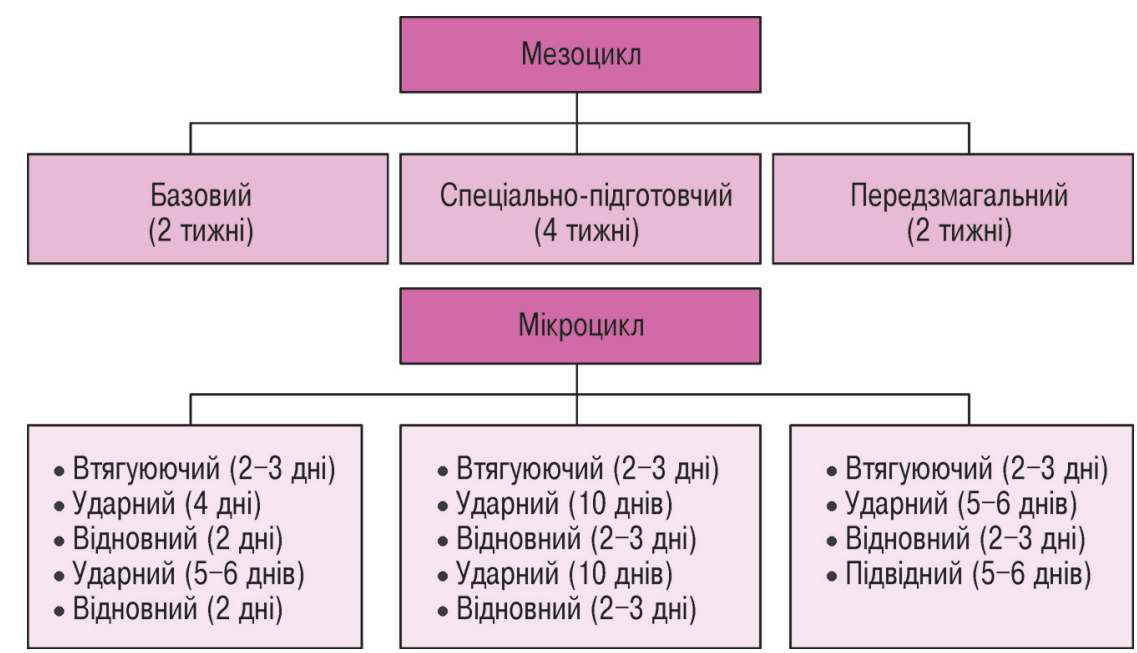

Рисунок 2 - Структура мезоциклів безпосередньої підготовки більярдистів національної 
кваліфікованих спортсменів за допомогою тестів, в основу яких лягли попередні розробки фахівців та вправи, що використовувалися в індивідуальних програмах.

Визначено кореляційний взаємозв'язок між показниками рівня спеціальної фрізичної підготовленості та ефективності змагальної діяльності висококваліфікованих більярдистів: 2016 p. $-r=0,96(p<0,05) ; 2017$ p. $r=0,98(p<0,05) ; 2018$ p. $-r=0,99$ $(p<0,05) ; 2019$ p. $-r=0,96(p<0,05)$.

Порівняння рангу спортсмена у рейтингу та коефіцієнта ефективності змагальної діяльності висококваліфікованих більярдистів має характер від'ємної кореляційної залежності і є оберненою: збільшення величини коефіцієнта пов'язане зі зменшенням номера у рейтингу протягом 2016-2019 рр. Так, відповідно до років, поданих вище: $r=-0,76(p<0,05)$; $r=-0,76(p<0,05) ; r=-0,67(p<0,05)$; $0,87$ ( $p<0,05)$. Місце спортсмена у національному рейтингу та відсоток максимального рівня спеціальної фрізичної підготовленості висококваліфікованих більярдистів також має від'ємну кореляційну залежність: $r=-0,66(p<0,05) ; r=-0,76(p<0,05)$; $r=-0,66(p<0,05) ; r=-0,88(p<0,05)$ (у 2016-2019 рр. відповідно).

Аналогічні дослідження у 2020 2021 рр. вказують на середній зв'язок між показниками спеціальної фрізичної підготовленості та ефективності змагальної діяльності більярдистів національної збірної команди України, що пояснюється наслідками карантинних обмежень у тренувальному та змагальному процесах і підтверджується коефіцієнтом кореляції $r=0,65$ $(p<0,05)$. Місце, яке посідає спортсмен у рейтингу 2020-2021 рр., та коефіцієнт ефективності його змагальної діяльності мають від'ємну середню кореляційну залежність, а саме: $r=-0,40(p<0,05)$. Місце спортсмена у національному рейтингу та відсоток максимального рівня спеціальної фізичної підготовленості висококваліфікованих більярдистів має від'ємну кореляційну залежність, де $r=-0,70$ $(\mathrm{p}<0,05)$.

Окремо розрахунки проводили для жіночої національної збірної ко- манди України з пулу, де обчислювали коефіцієнт ефективності змагальної діяльності на період 2016-2021 рр. В основу планування навантажень у тренувальному процесі жіночої збірної команди було покладено корекцію тренувальних впливів залежно від стану спортсменок. Програмування спеціальної фрізичної підготовки в різних фразах менструального циклу є досить ефективним засобом, який відповідає сучасним вимогам методики спортивного тренування під час підготовки жінок у більярдному спорті.

У кожному макроциклі під час безпосередньої підготовки до головних змагань на навчально-тренувальних зборах визначали рівень спеціальної фізичної підготовленості висококваліфікованих більярдисток. Було відмічено високий кореляційний зв'язок між рівнем їхньої спеціальної фрізичної підготовленості та ефективністю змагальної діяльності: 2016 р. - $r=0,88$, якщо $p<0,05 ; 2017$ p. $-r=0,98$ $(p<0,05) ; 2018$ p. $-r=0,78(p<0,05)$; 2019 p. $-r=0,91(p<0,05)$. Ранг спортсменки у рейтингу 2016-2019 рр. та коефіцієнт ефективності змагальної діяльності створює від'ємну кореляційну залежність, де $r=-0,89(p<0,05)$; $r=-0,93(p<0,05) ; r=-0,87(p<0,05)$; $r=-0,74(p<0,05)$ відповідно до вказаних вище років. Місце спортсменки у національному рейтингу та відсоток максимального рівня спеціальної фрізичної підготовленості також має від'ємну кореляційну залежність, a саме: $r=-0,84(p<0,05) ; r=-0,90$ $(p<0,05) ; r=-0,46(p<0,05) ; r=-0,77$ $(p<0,05)$ (у 2016-2019 рр. відповідHO).

Аналогічні дослідження у 2020 2021 рр. дозволили встановити кореляційний зв'язок між показниками спеціальної фрізичної підготовленості та ефективності змагальної діяльності більярдисток національної збірної команди України, що пояснюється наслідками карантинних обмежень у тренувальному та змагальному процесах і підтверджується коефріцієнтом кореляції $r=0,74$ ( $p<0,05)$. Мicце, яке посідає спортсменка у рейтингу 2020-2021 рр., та коесріцієнт ефективності її змагальної діяльності має від'ємну середню кореляційну залежність, а саме: $r=-0,73(p<0,05)$. Ії місце у національному рейтингу та відсоток максимального рівня спеціальної фізичної підготовленості також має від'ємну та невисоку кореляційну залежність, де $r=-0,29(p<0,05)$.

Реалізація розробленої нами програми підготовки до головних змагань макроциклу у педагогічному експерименті виявила вірогідне поліпшення інтегральної підготовленості в експериментальній групі (ЕГ) спортсменів національної збірної команди 3 пулу до чемпіонату Європи порівняно з контрольною групою (КГ) $(p<0,05)$. Наукове обґрунтування практичної ефективності впровадження у процес підготовки національної збірної команди з більярдного спорту (пул) підтверджено високими результатами виступів більярдистів ЕГ на чемпіонатах Європи з пулу 2016-2019 рр.

Для розробки модельних характеристик психосрізіологічного стану більярдистів під час турніру нами було розраховано такі показники спортсменів основного складу національної збірної команди України 3 пулу у змагальному мезоциклі: рівень спеціальної фрізичної підготовленості - 88,68 \%; якість функції рівноваги із зоровим контролем - 87,6 \% і без зорового контролю - $84 \%$, едрективність уваги - 87,8 \%; обсяг довільної уваги - 87,36 \%; обсяг короткострокової пам'яті - 54,46 \%; коесріцієнт варіації середнього часу вирішення завдання - 48,78 \%; продуктивність - 80,8 \%; коефріцієнти мотиваційного, вольового та типологічного компонентів - $71 \%$; стресостійкість $88,2 \%$ (рис. 3.)

Конгломерація індивідуальних особливостей техніко-тактичної підготовленості кожного спортсмена та завдання календаря його змагальної діяльності порівняно з модельними даними психічного стану дозволяють визначити резерви рівня підготовленості спортсмена та шляхів подальшого удосконалення. У ході аналізу ефективності змагальної діяльності спортсмена важливого значення набуває саме надійність його резуль- 


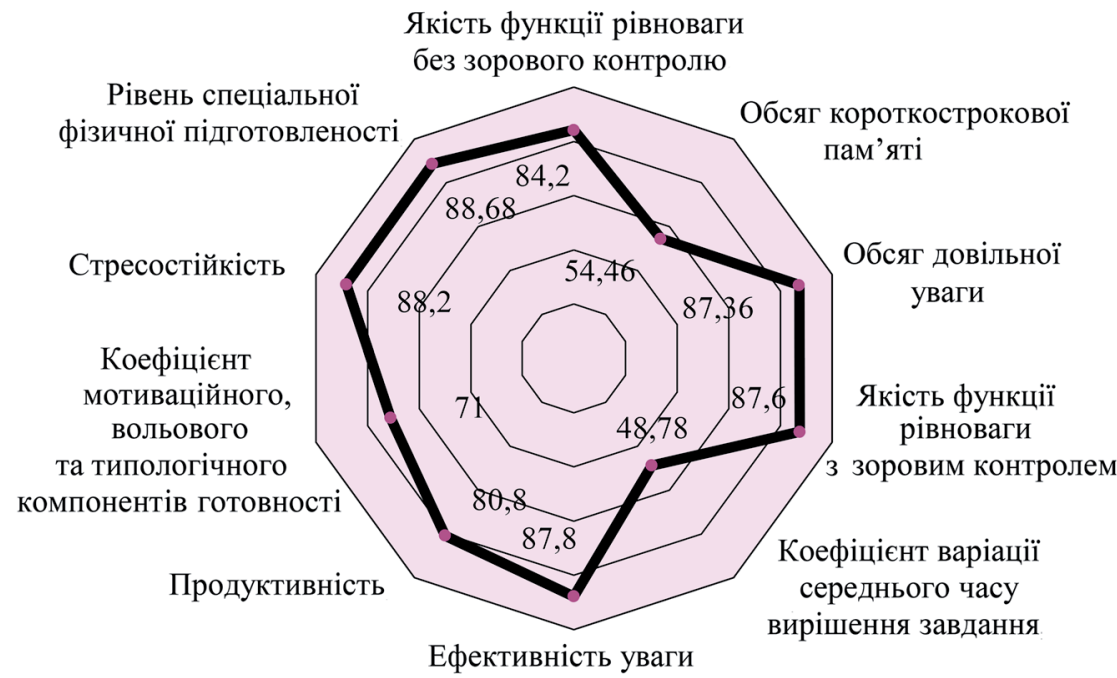

Рисунок 3 - Показники оптимального психофізіологічного стану висококваліфрікованих більярдистів під час головних змагань макроциклу, \%

тативних виступів на головних турніpax, що свідчить про високий рівень інтегральної підготовленості: фрункціональних, психічних, фізичних, мобілізаційних якостей.

\section{Висновки:}

1. Аналіз науково-методичної літератури свідчить, що в умовах сьогодення ведеться активний пошук шляхів удосконалення та підвищення ефективності змагальної діяльності висококваліфікованих спортсменів у спортивних іграх. Серед неолімпійських видів не є виключенням і більярдний спорт, де актуальним завданням постає досягнення високих спортивних результатів національною збірною командою з пулу на головних міжнародних змаганнях для отримання ліцензій на Всесвітні ігри. Дослідження сучасних програм підготовки висококваліфрікованих більярдистів встановили, що вони передбачають планування тренувального навантаження техніко-тактичної підготовленості без урахування диференційованого підходу до розвитку та вдосконалення спеціальних фрізичних якостей.

2. Вирішення проблеми можливе шляхом удосконалення системи відбору та підготовки національних збірних команд України до основних стартів сезону, в тому числі й Всесвітніх ігор, на основі застосування сучасних знань і методик спортивного тренування, медицини, біології та інфрорма- ційного забезпечення, враховуючи досвід провідних шкіл Європи.

3. Аналіз якісних та кількісних показників змагально-тренувального процесу висококваліфрікованих більярдистів, визначення місця та пріоритетності видів підготовки у програмах які покладено сьогодні в основу тренування провідних збірних команд Європи з пулу, дозволив розробити планування підготовки, що включає дифреренційоване навантаження зі спеціальної фрізичної підготовки з акцентом на вдосконалення спеціальних координаційних здібностей та витривалості.

4. Оцінка складових інтегральної підготовленості висококваліфікованих більярдистів дозволила встановити найбільш значущі види підготовки та показники. Відмічається високий прямий статистично значущий кореляційний зв'язок рівня спеціальної фрізичної підготовки відносно інтегральної, що прогнозовано має вплив на ефективність змагальної діяльності.

5. Між показниками рівня спеціальної ффізичної підготовленості та есрективністю змагальної діяльності висококваліфрікованих більярдистів у 2016-2021 рр. визначається високий прямий статистично значущий кореляційний зв'язок відповідно: $r=0,96$ $r=0,98 ; r=0,99 ; r=0,96 ; r=0,65$ $(p<0,05)$ у чоловіків; $r=0,88 ; r=0,98$; $r=0,78 ; r=0,91 ; r=0,74(p<0,05) y$ жінок. Аналіз отриманих результатів свідчить про високий рівень впливу показників спеціальної фізичної підготовленості висококваліфрікованих більярдистів на ефективність їхньої змагальної діяльності, що підтверджує необхідність корекції існуючих програм підготовки спортсменів національних збірних команд з більярдного спорту.

6. В основу планування підготовки жіночої національної збірної команди покладено корекцію тренувальних впливів залежно від психофрізіологічного стану спортсменок. Саме тому під час виконання тестів для визначення рівня спеціальної ффізичної підготовленості у жінок не було виявлено вірогідних відмінностей порівняно з чоловіками

7. Зміст розробленого програмного матеріалу базового, спеціальнопідготовчого та передзмагального мезоциклів враховує диференціацію навантаження за видами підготовки та інтервали відпочинку залежно від однієї з чотирьох дисциплін пулу з акцентом на спеціальну фрізичну підготовку спортсменів національної збірної команди. При цьому контроль навантажень має такі переважні відмінності: враховує специфріку тренувальних і змагальних навантажень у більярдному спорті; охоплює специфічні засоби, що характеризують зміст процесу підготовки висококваліфікованих більярдистів; дозволяє здійснювати контроль, обробку інфформації та корекцію програми в спеціальному додатку. Інноваційні розробки 3 дистанційними елементами тренування дозволили оптимізувати підготовку висококваліфрікованих спортсменів у період застосування карантинних заходів $2020 \mathrm{p}$.

8. Розроблена програма підготовки висококваліфікованих більярдистів до головних змагань макрациклу позитивно вплинула на ефективність їхньої змагальної діяльності. Так, коефіцієнт ефективності змагальної діяльності у спортсменів експериментальної групи після впровадження розробленого комплексу вправ зі спеціальної фрізичної підготовленості у тренувальний процес виріс на 2,6 \% у чоловіків та на 5,83 \% - у жінок порівняно з попередніми результатами. 
Перспективи подальших досліджень передбачають планування чотирирічного циклу підготовки висококваліфікованих більярдистів для досягнення запланованого спортивного результату на головних змаганнях річного циклу для відбору та участі у Всесвітніх іграх.

Конфлікт інтересів. Автори заявляють, що відсутній будь-який конфллікт інтересів.

\section{ЛIТЕРАТУРА}

1. Борисова ОВ. Современный профессиональный спорт и пути его развития в Украине (на материале тенниса): монография Киев: Центр учебной литературы; 2011. 312 с.

2. Борисова 0, Нагорна В, Митько А Індивідуальні підходи в програмуванні підготовки висококваліфікованих більярдистів. Вісник Чернігівського національного педагогічного університету імені Т. Г. Шевченка. 2018; 1(152):153-6

3. Борисова 0, Нагорна В, Перетятько A, Митько А. Програми підготовки висококваліфікованих більярдистів Європи: експертна оцінка. Фізична культура, спорт та здоров'я нації: зб. наук. праць. 2018;5 (24):160-7.

4. Борисова 0, Нагорна В, Перетятько A, Митько А, Пацура В. Підготовка висококваліфікованих більярдистів до головних змагань макроциклу. Теорія і методика фріз. виховання і спорту. 2019;(4):3-8.

5. Верхошанский ЮВ. Основы специальной физической подготовки спортсменов. Москва: Физкультура и спорт; 1988. 331 с.

6. Дрюков ВА. Подготовка спортсменов высокой квалификации в четырехлетних олимпийских циклах. Киев: Науковий світ; 2002. 240 с.

7. Дяченко А, Кірпич С. Спрямованість фрізичної підготовки боксерів до головних змагань із використанням специфічних функціональних характеристик. Спортивна наука України. 2018;6(88):20-32.

8. Захарьева НН, Барчукова ГВ. Влияние предстартовых состояний на спортивную результативность бильярдистов. Теория и практика физической культуры. 2013;(12):72-4.
9. Імас ЄВ, Матвеєв СФ, Борисова ОВ та ін. Неолімпійський спорт: навчальний посібник для студентів вищих закладів фіз. виховання спорту. Київ: Олімпійська л-ра; 2015. 184 с.

10. Костюкевич ВМ. Теорія і методика тренування спортсменів високої кваліфікації: навчальний посібник. Вінниця: Планер; 2007. 273 с.

12. Платонов ВН. Периодизация спортивной тренировки. Общая теория и ее практическое применение. Киев: Олимпийская лит.; 2013. 624 c.

13. Borysova O, Nagorna V, Pavlenko I, Shutova S, Mytko A, Shlonska 0, Peretyatyko A Tkachenko M, Sushko R. Psychological readiness of elite and well-trained billiard players for the main competitions of the macrocycle. SportMont 2021;19(2021):101-6.

\section{LITERATURE}

1. Borysova OV. Modern professional sports and the ways of its development in Ukraine (on the basis of tennis material): monograph. Kiev: Tsentr uchebnoi literatury; 2011. $312 \mathrm{p}$.

2. Borysova 0, Nagorna V, Mytko A. Individual approaches in programming the training of elite billiards players. Bulletin of the Chernihiv National Pedagogical University. 2018;1(152):153-6.

3. Borysova 0, Nagorna V, Peretiatko A, Mytko A. Highly skilled billiard training programs in Europe: expert assessment. Physical culture, spor and health of the nation: coll. of scient. papers. 2018;5 (24):160-7.

\section{ІНФОРМАЦІЯ ПРО АВТОРІВ}

Борисова Ольга Володимирівна https:orcid.org/0000-0002-2311-1921, borisova-nupesu@ukr. net

Нагорна Вікторія Олегівна https://orcid.org/0000-0003-2607-7412, cue@ukr.net Митько Артур Олександрович https://orcid.org/0000-0002-5139-3751, misterartur@ukr.net Національний університет фрізичного виховання і спорту України 03150, Київ, вул. Фізкультури,

\section{INFORMATION ABOUT THE AUTHORS}

Borysova Olha https:orcid.org/0000-0002-2311-1921, borisova-nupesu@ukr.net Nagorna Viktoriia https://orcid.org/0000-0003-2607-7412, cue@ukr.ne Mytko Artur https://orcid.org/0000-0002-5139-3751, misterartur@ukr.net National University of Ukraine on Physical Education and Sport 03150, Kyiv, Fizkul'tury str., 1 